\title{
Tuta e a cidade: arquivos domésticos das infâmias urbanas
}

\author{
Luis Artur Costa, Tania Mara Galli Fonseca \\ Universidade Federal do Rio Grande do Sul, Porto Alegre, RS, Brasil
}

Resumo

O presente ensaio utiliza estratégias biografemáticas para acontecimentalizar nossos arquivos domésticos da infâmia urbana. Não se busca juizo ou verossimilhança. Não se pretende dizer o que o personagem experienciou: seria sufocar mais uma vez sua voz. Pretende-se apenas experimentar ver que cidade se vê ao nos reinventarmos com o contágio-tuta. Que cidade se produz ao nos afundarmos nas heceidades da sua vida ao ponto de repensar as nossas? É deste modo que se busca acontecimentalizar nossa cidade com fragmentos infames em uma heterotopia doméstica que acontecimentalize os arranjos de subjetivação existentes em nossas cidades desde seu surgimento até a atualidade.

Palavras-chave: heterotopia; infâmia; cidade; doméstico.

\section{Tuta and the city: domestic's archives of urban infamy}

\begin{abstract}
This essay utilizes biographematics strategies to eventualization ours domestic's archives of the urban infamy. We do not search for judgment or verisimilitude. We want just an experimental act of assemblage. Which city we can produce when we are infect whit the singularities of other life? What we can see of our habits whit the life of an infamy? In this essay, we want to make an effort to reinvent ours domestic lives beyond the disciplinary and control strategies. Whit the heterotopia of an infamy life, we proposes an eventualization of ours domestic's archives.
\end{abstract}

Keywords: heterotopia; infamy; city; domestic.

Nesse texto, os autores pretendem alçar seu pensamento sobre a cidade através de um personagem conceitual que desencaixa e evidencia os mecanismos constituintes da urbanidade em nossa cultura. Chamada de Tuta, cujo nome de batismo seria Antônia. Nascida negra, pobre e mulher, Tuta foi adotada por uma família de ilustres. Foi considerada como criada, em dois sentidos: por ter sido adotada e por servir com seus préstimos domésticos aos pais-patrões. Criou-se dentre os filhos desses, crianças de sua mesma idade, tendo assumido o direito de chamar-lhes de doutor, em que pese o ridículo dessa titulação entre crianças. Trata-se, sem dúvida de uma vida qualquer que a qualquer um de nós poderá se apresentar como personagem intercessor. Tuta, nome tatibitate, próprio para crianças sem aperfeiçoada linguagem, despersonalizado e impróprio, apenas servindo à função de ser convocado com facilidade. Teria havido algum momento de esquecimento possível a você de nossa diferença? Somente anos depois é que viemos aqui falar da cidade de nossa memória e vimos você, já desaparecida e enterrada em cova rasa.

\section{1) A cidade individuando-se da saturação rural: o escravo e o trabalhador}

Abro os olhos. Vejo o teto da minha casa. Ainda que meu teto não tenha sido feito com grande personalidade eu o reconheço claramente. Meu teto não possui adornos. Aliás, nem gostaria destes. Muito tive de espanar as sujeiras que se aninham nas entranhas destes enfeites. Meu teto é liso. Ou melhor, reto. Pois possui algumas manchas de infiltrações e mofo que são a singular garantia de que despertei mais uma vez em minha casa. Sabe, eu

\footnotetext{
^Endereço para correspondência: Universidade Federal do Rio Grande do Sul, Instituto de Psicologia, Programa de Pós-Graduação em Psicologia Social e Institucional. Rua Ramiro Barcelos, 2600 - Sala 300j - Santana, Porto Alegre, RS, Brasil - CEP 90035-003.E-mail: larturcosta@gmail.com, tgallifonseca@gmail.com.
}

até gosto de ter essas manchas por perto. Não só por que estou fatigada de tanto apagar os restos do desastre do tempo pelos cenários domésticos das famílias. Apenas gosto de cultivar meu mofo cá acima de mim por que me é familiar, tem um aconchego de lar. Até no cheiro úmido e ocre da massa corrida esboroando encontro um afago de reencontro. Sempre vivi em lugares assim. Não, não me entendam mal. Vivi em boas casas, casas grandes e amplas com diversas janelas que emolduravam belos jardins tomados de três marias e roseiras. Muito tempo passei em salas amplas, de pé direito alto, com piano e móveis vindos do estrangeiro em largas viagens de navio. Muito caminhei por compridos corredores salpicados de portas e fotos dos ancestrais da família. Muita refeição fiz em grandes e agitadas cozinhas, com tinas de cobre e fogões a lenha a fumegar segundo o ritmo da lida diária. Carreguei jogos de porcelana mais leves e delicados que um pastel de santa clara. Mas em meio a tanta elegância e opulência eu tinha o meu quinhão de austeridade cristã. Vivia em uma peça ao fundo da casa, estrategicamente junto do alvoroço da cozinha. A dependência da empregada. Lá os móveis eram da madeira amarela e nua dos eucaliptos. Ali as xícaras eram grossas como a sola dos pés dos que trabalham na lavoura, exigindo dos lábios gestos pouco delicados para sorver aos líquidos. As dimensões da peça eram dignas de um claustro. Como não tinha janelas, apenas uma estreita porta, não raro a umidade contagiava e se infiltrava em cada grão de pó do quarto. O mofo era meu parceiro cotidiano nas curtas noites de sono entre $o$ despertar das crianças e o descanso dos adultos.

$\mathrm{Na}$ grande casa da antiga charqueada meu quarto fica junto à cozinha e o varal, espremido entre os afazeres domésticos nas margens da casa. Nas margens, mas ainda na casa, como um pé ou um traseiro que se usa o tempo inteiro sem lhe dirigir o olhar. Minha mãe fora escrava 
na fazenda e tivera uma vida muito mais dura. Andava envolta em andrajos cerzidos com restos de sacos de cereais. Capinava, semeava, colhia, ajudava na lida com o gado nos dias de grandes funções. Dormia no galpão, protegida por um pelego velho no inclemente inverno e direto sobre a frescura do chão batido no fastio do verão. Minha mãe dizia que antes as coisas eram piores: havia muito açoite, tição na carne e outras maldades. Mas algumas pessoas que vinham de Pelotas começaram a contar histórias de que a escravidão tinha acabado. Que os pretos estavam todos livres. Minha mãe pensava que não passava de conto de andarilho que fica de estância em estância inventando prosa pra passar o tempo do pito. Ninguém acreditava nestas histórias até que um dia o próprio patrão convocou toda a negrada e disse que quem quisesse poderia se ir. Mas quem ficasse continuaria ganhando teto e alimento em troca do trabalho. No final das contas, entre intrépidos e cautelosos pouca coisa mudou. Minha mãe ficou, uma mulher prenha não podia se dar ao luxo de aventuras incertas.

Nasci muito depois, em uma tarde quente do verão de 1941. Foi um alvoroço no galpão dos trabalhadores, teve festa. Assaram miúdos de ovelha. Tomaram pinga e bailaram. $\mathrm{O}$ nascimento de mais um dos nossos era uma nova vitória contra a morte e o esquecimento. A mulher do patrão apareceu uns dias depois do meu nascimento e chamou minha mãe para ser ama de leite de uma de suas filhas. Entrar na casa era motivo de inveja para muitos: comida melhor, roupas melhores, lida mais leve, ver de perto os senhores da fazenda, escutar suas conversas, ver suas louças, sentir seus perfumes. Toda uma nova vida se descortinava ao ultrapassar o marco da porta que dava para os fundos da casa grande. Aquela singela fronteira de madeira, tijolos e cal dividia dois mundos completamente distintos. Com sua compleição física vigorosa, minha mãe dava bastante leite e por largo tempo. Isso satisfazia muito a senhora do casarão. Ela pode amamentar a filha e duas netas da senhora, que nasceram uma logo após a outra. A longevidade da função de ama de leite de minha mãe fez com que eu crescesse dentro da casa, espiando por entre portas e frestas aquele mundo cheio de cores e brilhos. $\mathrm{Na}$ verdade, eu já me sentia muito mais parte do casarão da antiga charqueada do que do galpão. Eu tinha até medo dele: suas cores ocres e seus odores acres. Terra vermelha, tecido cru, sebo de ovelha, urina, fezes e brasas.

Em mais um golpe de sorte a senhora do casarão perdeu uma filha e se afeiçoou por mim pra compensar o luto. Passou a me levar para todos os lados da casa com ela. Eu ia ajudando em pequenas tarefas. Segurando a linha de lã enquanto ela tecia. Alcançando pequenos objetos. Levando recados para a cozinha. No dia em que minha mãe não produziu mais leite, ela voltou ao galpão, mas eu não. Ela sofreu muito com a separação. Eu tive medo de dormir sem minha mãe. Me aninhei no meu pequeno quarto e afeiçoei-me a cada infiltração daquelas paredes. O esmaecido da cal encharcada de umidade e o odor do bolor eram tristes, mas mais agradáveis do que aquele mundo de barro, carne, ferro e fogo das bandas dos trabalhadores da fazenda. Além disso, eu passava muito tempo pelos aposentos da senhora e das doutoras senhorinhas. A senhora tinha curso de professora frequentado quando jovem em Pelotas, e gostava de brincar de trabalhar ensinando para as filhas. Resolveu me ensinar também. Queria uma dama de companhia negra: que fala bom português, salpica termos em francês e servia de acordo com a empolada etiqueta dos chás a la europeia. Um luxo raro naquelas terras sem fim.

As letras me abriram um novo mundo naquele mundo já vasto do casarão. Eu mal frequentava os aforas da casa, nem dava linha aos gracejos dos demais trabalhadores da fazenda. Em minhas roupas limpas bem engomadas, com meu português de doutora senhorinha, me considerava melhor que todos os demais empregados. Mas sabia que não era senhorinha: eu era como um estranho bibelô, uma boneca de ébano exibida com orgulho a tocar piano para os poucos visitantes que recebia. Meu quinhão naquela nação era comer pelas bordas as regalias das vidas dos outros. Se em um instante minhas mãos magras folheavam mansamente livros vindos do além-mar, logo se exasperavam contra as matérias brutas das limpezas e cozinhas. Não posso dizer que não sofria com tantos contrastes, mas me regozijava a cada badalar da sineta que me chamava para junto de figuras tão imponentes quanto as dos meus benfeitores.

Acontece que com o passar do tempo minhas funções se tornaram obsoletas. Eu já tinha vinte anos e não era mais uma menininha. Isso fazia com que a comiseração dos demais por mim diminuísse geometricamente com cada sinal de maturidade a apagar as fofuras juvenis. A lida dura da casa enrijeceu meus dedos e estragou minha performance no piano. Minha velha senhora morreu junto da importância do francês e dos talheres de prata bem postos. Suas filhas, minhas senhorinhas de criação, foram estudar em Pelotas e até na capital, casaram e fizeram suas casas por lá. Voltavam por vezes para a imensidão claustrofóbica dos pampas, mas com as cabeças abertas para os novos ventos que sopravam em outras aragens do mundo. O cheiro de mofo entranhado nas grossas paredes daquela velha casa já não lhes interessava mais, assim como seu velho mobiliário e criadagem. Os rituais francófilos empolados para chás e jantas eram agora marca do atraso. $\mathrm{O}$ mundo precisava de mais agilidade. Um tal pragmatismo tomava conta dos gestos delas: modos mais soltos e despretensiosos. Abandonaram o cálculo preciso da etiqueta em nome do conforto e modernidade. Suas roupas eram outras, tomavam chá com as duas mãos se aquecendo na xícara, ou até bebiam café em pé enquanto fumavam um cigarro com gestos amplos, pouco comedidos, de uma maneira tão masculina que certamente faria sua velha mãe corar. Um certo desespero laçou meu estômago quando diante desta cena percebi o olhar perscrutador de uma delas sobre mim. Mirava-me como quem vê algo muito estranho. Percebi que eu não cabia mais naquele novo mundo e temi pelo meu futuro. Lembrei do galpão, do seu chão, do seu cheiro. Entre uma baforada e outra, minha senhorinha, agora grande, começou a falar sobre mim com suas irmãs. 
Uma empregada que é bem letrada é já um luxo descabido. É até meio brega! Coisa antiga. Os tempos são outros, vivemos na modernidade, temos que ser práticos! Precisamos é de uma casa limpa e boa comida na mesa, nada mais! Esses móveis em madeira, cheios de rococós para a poeira se entranhar são terriveis! Hoje temos tantos materiais mais práticos, impermeáveis, lisos e fáceis de limpar! Mesmo esse hábito das amas de leite, ainda que prático me parece pouco higiennico e até indecente! Hoje existem diversas marcas de leite em pó que substituem com diversas vantagens o leite materno! Vá saber o que passa pelas tetas de uma ama?! Acho muito animalesco e ultrapassado esse costume. Além de ser coisa ainda da época da escravidão, não se pode mais permitir tamanha exploração de um ser humano! Aliás, tocando neste assunto, temos que ver o que faremos com a Tuta... ela é um desperdicio de dinheiro abandonada aqui.

Eu tremi e deixei resvalar os talheres no piso que cindiram um ruído agudo no silêncio. Minha senhorinha voltou os olhos para mim e desferiu:

Desculpa Tuta, mas não precisa chorar não. Para com essa cena. Sei que te ajudamos bastante até hoje, mas agora são outros tempos! Tens que te atualizar! Profissionalizar! És como uma irmã para nós, mas tens de fazer tua própria vida! Não podes ficar aqui nesta casa como se fosse uma escrava do século passado. Ai, ai, tá. Enxuga essas lágrimas mulher! Quanto drama. Eu vou pensar em algo. Pode levar as coisas pra cozinha agora, por favor?

Nem sentia minhas pernas enquanto caminhava com a baixela mal equilibrada sobre meus braços trêmulos no caminho para a copa. Eu não havia entendido nada do que ela dizia, apenas conseguia me lembrar do chão e do cheiro do galpão. Ser retirada das paredes daquela casa era, para mim, como ser deixada no deserto a minguar, longe de qualquer abrigo. Eu mal dormia naqueles dias durante a estada da nova senhora na fazenda. Trabalhava com todas minhas forças antes que eu pudesse ser convidada a me retirar daquele lar que não me pertencia. Após alguns dias a senhorinha que falara comigo naquela tarde gritou meu nome. O mundo se congelou por alguns instantes quando ouvi sua voz clamando minha presença na sala. Tinha certeza que seriam meus últimos passos naquela casa, por isso fui sorvendo cada cor, cada odor, cada figura de cada objeto, atrelando cada novo elemento a uma série de velhas lembranças. Queria me agarrar àquela casa em minha memória para que se eu fosse expulsa, ao menos ela jamais saísse de mim. Engasguei com um grito na garganta e quase morri de alegria e medo quando ouvi a notícia: ela decidira me levar para trabalhar de governanta em sua casa de Pelotas. Eu até ganharia um soldo pelo meu trabalho! Teria roupas novas adequadas aos novos tempos. E conheceria a cidade!

A minha nova patroa tagarelava sem parar ao lado do marido no carro enquanto eu tentava escutar tudo calada no banco de trás. Dizia ao marido como andava difícil encontrar uma boa empregada, pois todas eram insolentes e dadas aos namoros e bebidas, "quando não aos roubos" sussurrou baixinho no ouvido dele dando uma olhadela para trás. "Uma moça do interior é o ideal.
Não conhece ninguém em Pelotas, só nós. É quase uma parente, não é Tuta? E até francês a danada arrisca!" O carro parou na porteira e finalmente transpassou a cerca de arame que delimitava a propriedade. Tuta sentiu um pouco de náuseas, sem saber se motivadas pelo sacolejar do automóvel ou se por pela primeira vez ultrapassar definitivamente aquela fronteira tão sutil quanto bem delimitada. Aquela cerca delimitava sua terra natal, seu pago, sua querência. De um golpe, as diferenças entre o galpão e o casarão já não pareciam tão grandes. Até daquele espaço acre e ocre ela já sentia saudade. A parede de tijolo caiado da casa, a parede suja de terra vermelha do galpão, a mangueira de pedra no entorno das casas, a cerca de arame amarrando tudo junto dentro da estância. Nó depois de nó o mundo de Tuta se desfazia. Mas agora era tarde, pouco adiantava chorar pitangas apodrecidas. Tuta não chorou a partida, sentia muito medo e felicidade diante de tantos novos perigos e maravilhas. "Que venha a cidade", para si mesma dizia.

\section{2) A cidade e suas fronteiras internas: consistências da civilidade disciplinar}

Abro os olhos. Vejo o teto da minha casa. Ainda que meu teto não tenha sido feito com grande personalidade eu o reconheço claramente. Meu teto é liso, ou melhor, reto. Pois possui algumas manchas de infiltrações e mofo que são a singular garantia de que despertei mais uma vez em minha casa. Moro em um pequeno quarto contiguo à cozinha no apartamento de minha patroa. A cidade é muito úmida e minhas paredes estão a descascar, pois a única entrada de luz são duas janelas basculantes que dão para um grande poço de luz bem no meio do prédio. Ali neste oco do edifício, retumbam centenas de vozes e sons vindos das pequenas vidas vividas juntas, apartadas apenas por pequenas paredes de alvenaria e gesso. Logo que cheguei passava muito tempo escutando pela janela aqueles retalhos de vidas a costurarem uma larga colcha cotidiana bem no meio do prédio. Era como um bando de caturritas alvoroçadas com o final da tarde na estância, mas aqui cada uma cantava ao seu modo: peleias de mãe e filho, casais fazendo as pazes, rádios acompanhando o chiar de panelas, repórter de tevê conversando animadamente com pais de família, copos que se estraçalham no chão e muitos chamados pelas empregadas. Como eu não tinha tevê nem rádio, ficava lá a escutar aquelas vidas murmurarem. As únicas janelas voltadas pra rua eram nas peças sociais da casa. Eu gostava de limpar os vidros demoradamente olhando curiosa o movimento da cidade diminuído pelos treze andares do prédio. Mas de perto, a rua me assustava de sobressalto. Logo que cheguei, eu tremia toda vez que minha patroa me pedia pra fazer compras na rua. E esse medo todo não era pelo receio dos assaltos e violências que sangravam nos jornais diários. Era medo da cidade mesmo. É tudo muito difícil para mim que estava acostumada a uma geometria das imensidões e ao ritmo calmoso das safras, épocas de tosquia e de abate. O esquadro largo e o movimento lento da campanha tinham formado minha sensibilidade. Aquela geometria densa de justaposições e sobreposições, onde um mora sobre o outro, somada àquele ritmo frenético de simultaneidades me produziam 
vertigens. As tonturas e dores de cabeça começaram lá pelo terceiro dia, quando me enfarei de tanta novidade e se iniciaram os mal-estares. Bastavam alguns minutos na rua para que meu labirinto perdesse o prumo naquele outro labirinto feito de frenesi: roncos, luzes, conversas, buzinas descompensadas a pedir mais velocidade, corpos que roçam em outros corpos que nem ao menos sabem os rostos dos ombros que lhes tocaram. Eu, aturdida, abaixava a cabeça e ia com um passo curto, mas decidido, abrindo caminho no marulho gentio. Só sendo desconhecido de todo mundo pra viver tão amontoado. Se não, só de cumprimentar cada um e perguntar da vida, se levava uma eternidade em cada esquina.

\section{1) Desdobrando o solilóquio: as artes da segmentação urbana}

Em seu solilóquio acima, Tuta abre uma das feridas do urbano: nesta história de viver juntos, sempre foi preciso inventar uma arte da segmentação, uma arte de como se relacionar ou separar das demais pessoas que formam uma cidade. Na ágora grega, por exemplo, existia o orthus: "O cidadão procurava andar de forma determinada e tão rapidamente quanto possível, através do torvelinho, encarando calmamente os estranhos [...] comportandose em público com austeridade, sem se confundir na multidão" (SENNETT, 1997, p. 50). Com o crescimento e aceleração das cidades surgiram outros andares menos altivos mas mais ativos e decididos: o "passo inglês" ou "andar à americana" (SEVCENKO, 1998, p. 551), que deram às pernas um passo mais largo e deixaram o olhar apontado reto para seu objetivo no horizonte, ignorando toda e qualquer distração do caminho. O caminhante apenas vence os obstáculos avançando inclemente. Afirmar-se em meio à turba da urbe tornou-se uma arte muito especial para os modernos. Em 1840, os americanos trocaram a conformação do transporte férreo de cabines com bancos voltados um de fronte ao outro, para grandes linhas de bancos virados na mesma direção, onde cada passageiro não teria mais que desviar constrangido o olhar do seu possível interlocutor dianteiro, já que via diante de si apenas uma nuca e cabelos (SENNETT, 1997, p. 277). A tolerância e a indiferença se tornaram os nortes flexíveis dos átomos a formigarem na massa frenética das cidades. Apenas ignorando ao outro, ao estranho e ao meio conhecido, torna-se possível habitar a urbe. O "viver junto" é garantido pelo "estar separado": "afinal, tenho ao meu alcance a solidão que tanto desejei, pois em nenhum lugar pode-se estar mais sozinho do que em meio a tanta gente que é preciso forçar caminho" (GOETHE, 1786 apud SENNETT, 1997, p. 227).

Tuta voltou ao prédio após uma saída ao mercado. Abraçava a si mesma agarrando aos próprios braços em um gesto de proteção diante da fúria citadina que ainda lhe invadia e rompia com sua intimidade. Já deixara o caos das ruas e subia no elevador de serviço, espécie de transporte coletivo vertical destinado aos serviçais (e não aos serviços). De início a patroa de Tuta deixara bem claro que o elevador mais austero era destinado para seus deslocamentos cotidianos pela espinha predial. Isso era para evitar constrangimentos mútuos pelo confronto entre as diferenças. Tuta entendia perfeitamente. Ela não via problemas e se sentia aliviada de não ter de dividir o elevador com senhoras e senhores tão distintos como os moradores daquele edifício. O silêncio que servia tão eficazmente como tecnologia de segmentação nas ruas para evitar o contato com os estranhos, se tornava uma ferramenta inadequada no elevador. O silêncio e a indiferença quando utilizados em espaços muito diminutos produzem uma série de efeitos colaterais que levam ao constrangimento das partes quietas: pigarros, cacoetes corporais, assobios, acessos de riso, entre outros. Tal inadequação da tecnologia social do silêncio para pequenas dimensões leva a outros subterfúgios mais adequados para evitar o contato íntimo nestas áreas. Um ótimo exemplo é o ato de perguntar ou efetuar considerações sobre o clima. Em geral, este estratagema alternativo, quando bem usado, permite aos convivas compulsórios evitarem a conversação íntima através de uma conversação impessoal. O silêncio tampouco é recomendado como estratégia de segmentação para os ambientes domésticos. Nestes, em geral, ficar junto em silêncio exige já algum grau de intimidade. Deste modo, convém aos criados de casa que se abstenham da convivência espacial quando seus serviços não são requisitados naquela peça. Do contrário, arriscam aparentar vigilância em busca de mexericos para frutificar no elevador de serviço ou na quitanda.

"No apartamento da patroa eu me sinto segura", pensava Antônia, "não na rua". Do mesmo modo que os salões e quartos do casarão a protegiam das agruras do rústico galpão, aquele apartamento servia de nau para navegar nas intempéries da cidade. Da mesma maneira que a crueza do galpão exigia a crueldade do capataz para dar ordem às coisas, o torvelinho caótico da urbe exigia a mão forte da polícia para obrigar o complexo a ser simples. Tuta apenas faria a ressalva de que aquela pequena sala jamais poderia receber um piano como o casarão da estância. Se no século XIX era moda entre os abonados de Pelotas possuir um piano no salão de receber para promover sarais, jantares e outras confraternizações, naqueles dias modernos isso já não era mais hábito. É no século XIX que surge este novo espaço de socialização privado no Rio Grande do Sul: a sala de jantar. Antes, as refeições das famílias costumavam ser feitas em uma varanda aos fundos da casa, com certa simplicidade e sem muita ostentação (SYMANSKI, 1998). Tal peça findou por ser fechada e nela passaram a se investir montantes consideráveis em aparelhos de jantar fornidos de porcelanas e pratarias. Vê-se, deste modo, a atenção voltando-se ao ambiente privado, o qual vai adquirindo não somente o status de local para socialização, como também espaço de conforto e vivência. A interioridade das casas vai se complexificando à medida que complexifica-se a noção de conforto e de privacidade no aburguesamento europeu das cidadelas do novo mundo. Mas nos nossos dias, se a importância do espaço privado apenas cresceu, as casas encolheram e os lazeres e convescotes mudaram. Dos grandes salões para jantares e chás ao som de piano, passamos para as salas de estar medianas ou minúsculas 
com a sonorização de televisores e rádios a embalar frugais refeições entre membros de um núcleo familiar diminuto. A sala perdeu a pompa e se popularizou. Os móveis se tornaram mais pragmáticos e higiênicos, com linhas retas e diagonais. Sem a organicidade vitoriana a higiênica estética industrial se proliferou para além das vilas operárias. A sala de receber virou de estar e o mobiliário reproduzia a simples geometria familiar e não mais a das grandes confraternizações: poltrona do pai, a cadeira da mãe, o sofá das crianças, tudo envolvido pelos sons e imagens captados das ondas eletromagnéticas. Tanto a tevê quanto o rádio não estão associados com a comunhão dos familiares com a cidade através de dispositivos eletrônicos.

A casa compõe a experiência da cidade burguesa. Fez parte das grandes reformas higienistas o cuidadoso planejamento das moradas: de suas fachadas ao seu interior. Os bairros operários pulularam pelas bordas da cidade, financiados por notáveis que "fidalgamente" construíam residências para serem alugadas aos menos afortunados. ${ }^{1}$ Tais novas moradas se apresentavam como habitat ideais para o cultivo da correção e saúde na alma proletária segundo as ideias da época. “As classes pobres e laboriosas, além do mais necessitam de habitações higiênicas, saindo de casas insalubres - ponto de partida de todos os vícios, de todas as calamidades que afligem o seu estado social" (Relatório apresentado pelo Intendente Dr. Pedro Luís Osório em 1922, p. 36 e 37. CEDOV, BPP apud GILL, 2006, p. 49).

A casa, o habitat, não simplesmente nos isola, mas nos une: o habitat é a fusão da casa com os hábitos, são as "paredes vibráteis", o recorte de um território existencial ao qual se dá vida sem necessária organicidade. "A teia da aranha contém um retrato muito sutil da mosca que lhe serve de contraponto" (DELEUZE; GUATTARI, 1997, p. 239). Por isso a construção do espaço doméstico é um importante agenciamento da nossa experiência urbana. No entanto, as relações entre a casa e a cidade na maioria das vezes não são ternas, mas sim tensas. Quando da época da escravidão, os senhores abastados podiam se dar ao luxo de possuírem escravas destinadas apenas para a lida doméstica e outras que se dedicavam às rotinas rueiras (BELARDINELLI, 2009; CARVALHO, 2008; CUNHA, 2007). Era importante dividir entre ambos os fluxos para que os mesmos não se contaminassem: que as informações sobre a vida privada da casa não proliferassem pelos ouvidos dos transeuntes e para que as imundícies das ruas não entrassem no ambiente imaculado do lar: as sujeiras químicas e morais das ruas poderiam originar miasmas no ambiente familiar. No entanto, o encarecimento dos escravos e a sua libertação fez com que muitos senhores tivessem que utilizar uma mesma criada para as lidas domésticas e das ruas. O cuidado com

\footnotetext{
${ }^{1}$ Enquanto em muitas cidades brasileiras foi a abertura de novas avenidas na virada do século XIX para o XX que possibilitou a demolição dos cortiços e a construção de residências adequadas, em Pelotas tal gesto não foi necessário. A retirada das casas e pessoas pauperizadas prescindiu das demolições e se utilizou de duas estratégias de mercado: altos impostos no centro e vivendas a baixos preços na periferia. A sobretaxação de $20 \%$ dos impostos urbanos sobre as casas da zona central que alugavam quartos e o fomento da construção de loteamentos baratos, higiênicos e distantes, fez as vezes da polícia e das grandes obras.
}

o que entra e sai dos lares sempre permeou a conduta das criadas domésticas, já que elas eram o ponto fraco na divisão entre o público e o privado: permissividade que devia ser objeto de cuidado na governança do lar. Um cuidado delegado para mulheres: castidade do lar.

Comte (1978, p. 128-130) já propalava o pendão das mulheres para as funções do lar: o cuidado e o afeto são metiers femininos: "A mulher e o sacerdote, os dois elementos essenciais do verdadeiro poder moderador, ao mesmo tempo doméstico e cívico [...] subordinação da inteligência à sociabilidade, diretamente representada pela verdadeira natureza pessoal e social da mulher". Assim, para os urbanistas positivistas do sul brasileiro, a mulher e as criadas tinham uma importante função na eliminação dos miasmas domésticos e no cultivo de uma subjetividade urbana. Independentemente dos preceitos higienistas para os lares, o fato é que Tuta pensava consigo em um novo solilóquio.

\section{2) Solilóquio acerca da domesticidade}

Eu cuidava de todos com muito esmero. Dobrava suas meias com jeito, já planificando o futuro instante de calçalas. Limpava os cantos recônditos e bordava às bordas vulgares dos panos de prato com carinho e dedicação. Sentia gosto em acarinhar cada um através de cada tarefa doméstica: movimento de ordenação cotidiana que transformava aquela casa em um lar. Como doméstica eu era um espaço sem nome entre diversos espaços: era da família e não era, era da rua e não era, era profissional, mas também não era. Me consideravam de grande confiança, mas tinham também muitas pequenas desconfianças. Eu era conhecida e desconhecida, instrumental e afetiva, suja e limpa. Me viam como uma das facetas do perigo marcado pela presença de entes pouco civilizados no seio do lar: criados, crianças, loucos, jovens e enfermos. Enquanto os infantes eram a possibilidade constante da irrupção de uma natureza selvagem nos quartos de banho ou dormitórios, a empregada era a possibilidade de mácula da casa pela rua. Ambos, jovens e criadas, deveriam ser constantemente vigiados. Não é por nada que muitas vezes fosse exatamente tão temido o encontro destes em suas moradas. Eu, de minha parte, ignorava ambos os olhares: o de agressivo desejo do filho do patrão e o de desconfiança vigilante da patroa. Deveria me sentir ofendida, mas a obediência me fazia vergar o lombo àquelas chibatadas sutis. Como se já não bastasse me defender na rua dos gracejos grosseiros por me encontrarem como uma presa fácil: sem pai, marido ou irmão, apenas patrão. Aqueles vapores das matérias em decomposição por todos os lados é que enlouqueciam os homens nos mercados. Isso e o álcool! Uma das principais ferramentas da degeneração humana. Por essas e outras que eu passava em um zumbido pelas ruas do mercado, esquivando-me dos galanteios impertinentes. Por isso, buscava guarida a lustrar, espanar, enxaguar, cozinhar e tantos outros verbos laborais que preenchiam de sentido minha vida. Nos dias mais tensos, quando me tornava apátrida em minha própria casa pelas suspeitas dos senhores, me esgueirava assim que possível para meu pequeno quarto e ficava a fitar o teto embolorado, como 
quem contempla um céu estrelado. Não, não fique com pena. Sei que para os demais da casa aquela mancha rugosa apenas confirmava minha ação como foco dos miasmas domésticos. O próprio termo miasma veio do grego e se referia no teatro à mancha de sangue que serve como marca da tragédia que seguirá um assassino (MARTINS et al., 1997). Assim, para a teoria miasmática, as manchas oriundas dos vapores e de matérias orgânicas eram a marca da morte a anunciar a tragédia vindoura: pestes, adoecimentos, loucuras, entre outros males. Mas aquele bolor a se espalhar pelo meu teto era meu firmamento pessoal, longe da mundana cidade e seus horrores.

Para mim, a cidade era uma pústula, uma ferida a jamais cicatrizar, para sempre me lembrar de minhas terras perdidas. Pouco senhora para o lar que eu não tinha, muito senhora para a rua que eu não podia. $\mathrm{Na}$ rua tem tanto estampido, é tanto o alarido. Tanto corpo ladeando o meu, lambendo ombro no ombro sem dengo, só pressa. E quando volto pra casa, me olham como quem vê a rua. Tudo por que eu elimino os tufos de cabelo dos ralos, poeira de peles mortas, camadas de gordura a sufocarem superfícies, entre outros restos da vida cotidiana que serviam de guarida para a proliferação de miasmas. Minha presença lembra a todos de sua vã animalidade, do sangue, do esperma, da urina, das fezes e das comidas apodrecidas, entre outras opacidades que mancham a vida polida. Eu sou a operação a tocar sujidades que ninguém quer ver para garantir a atmosfera límpida que todos desejam ter. Sou o enforcamento do criminoso do qual todos desviam os olhos horrorizados, ainda que apreciem a segurança garantida pelo carrasco.

\section{3) A fonte da cidade: domesticando o urbano}

Assim como a vergonha que acompanhava Tuta, a cidade e os lares lutam para enterrar fundo sua demasiada humanidade. "Pelotas vem sendo saneada, recebendo pela rede hidráulica que é o sistema arterial das cidades, o sangue puro e vivificante [...], expelindo pela rede de esgotos, que é o sistema venoso das cidades, o sangue viciado que deve ser jogado longe" (Discurso do Engenheiro Octacilio Pereira publicado no Relatório da Intendência de 1922 apud SOARES, 2000, p. 15).

A cidade de Pelotas era como uma pérola da civilidade a encobrir com sua fina camada brilhante o sangue e a carne que fomentavam a economia local. O dinheiro saturara tanto naquela região rural com o crescimento das charqueadas que acabou se precipitando em uma série de palacetes e quadras urbanizadas. $\mathrm{O}$ capital da carne salgada de rezes e escravos, começou a se sedimentar na forma de uma cidade. Os charqueadores, com suas portentosas fortunas dignas das maiores capitais, se viam diminuídos no tédio cru do pampa. Cortaram o solo indômito com o esquadro humano de uma cidade planejada: um tabuleiro de xadrez com a catedral ao centro. É tocante andar por suas ruas constituídas e perceber a força com que tentam esconder sua origem bruta e vulgar sobre a opulência exagerada das fachadas ecléticas. A cidade de Pelotas negou seu entorno e alucinou Paris na gélida tundra subtropical. Os viajantes do século XIX e do início do século XX relatavam que ao chegar à cidade eram recebidos por um ar denso e úmido, de um odor tão intenso que fazia as narinas arderem. Nuvens de moscas e insetos varriam a cidade, infestando salões e pratarias festivas. A cena escatológica é sustentada pelos muitos arroios do entorno da cidade. Nas suas beiras, edificaram-se as charqueadas para facilitar o escoamento da produção. Como a cada rés carneada seus restos, sangue e entranhas, eram jogados nos rios, estes eram sufocados por um manto denso de matéria orgânica em decomposição a compor com fétidos vapores a atmosfera da bela urbe (LORNER; GIL; SCHEER, 2012; MÜLLER, 2010; SOARES, 2000). Como um feto envolvido em sua placenta, a cidade crescia alimentada por aquela massa orgânica a fluir ao seu redor. É comovente acompanhar as convulsões higienistas a transformar o espaço urbano em uma luta infeliz por esconder a barbárie que constrói nossa civilização. Para tanto, filtram a violência e a dispõe de modo harmônico, em medidas iguais e simétricas segundo técnicas validadas pelas últimas descobertas científicas. Tais pequenas violências disciplinares servem para imprimir ordem ao corpo indócil daquelas terras. ${ }^{2}$

A fonte de ferro fundido da praça central nos permite clarões de compreensão sobre estes movimentos que construíram esse aglomerado urbano. Foi importada da França uma fonte para prover água limpa à população. Foi posta na atual praça Pedro Osório, sobre a base de um antigo pelourinho. Havia que se tamponar aquela vergonha escravocrata com uma maravilha civilizada voltada para o bem de todos. Ali onde antes ocorriam crueldades pouco arrazoadas, agora todos poderiam matar sua sede de modo higiênico. No entanto, se antes tal praça se prestava aos espetáculos pouco polidos do pelourinho, no final do século XIX já era mais dada aos passeios cordiais da elite citadina. Com a fonte, muitos criados e lavadeiras passaram a frequentar também a praça. Aquela lambança do gentio buscando água e emporcalhando o passeio com sua algazarra logo foi criticada nos jornais e levou a uma série de medidas: primeiro cercaram a fonte e restringiram os horários de abastecimento com um guarda, por fim, se proibiu a coleta da água reduzindo a antiga fonte a um elemento de adorno que embelezava os passeios (XAVIER, 2010, p. 65). Mas já em 1980, Tuta evitava a fonte e a praça degradadas, tomadas pelos degredados da cidade: moradores de rua e afins.

\section{4) A implosão do doméstico sob o peso do urbano: irrompe a tutela de Tuta}

A patroa de Tuta pediu que ela fosse fazer as compras da semana. Mas Antônia não estava bem naquele dia. $\mathrm{O}$ clima estava úmido e quente, com uma massa escura de nuvens a trovejar uma chuva que insistia em não cair. Essa atmosfera deixava os nervos de Tuta em frangalhos. As feridas da cidade em sua pele lancinavam. Com

\footnotetext{
2 "La ciudad estaba recibiendo en estos momentos los ferrocarriles, el teléfono, la industria, casi simultáneamente a la expansión mundial de estas innovaciones, mientras que las estructuras sociales locales vivían aún tímidamente la transición de una sociedad esclavista hacia las relaciones sociales típicamente capitalistas [...] la élite local, que ha sido caracterizada como una aristocracia ilustrada y extravagante (tall aristocracy) con una base de explotación esclavista, estaba atenta a las modas e ideas mundiales e importó los conceptos higienistas para el sur de Rio Grande do Sul, una sociedad urbana aún en gestación” (SOARES, 2000).
} 
alma esfarrapada, ficou a implorar para não ir. A patroa respondeu: "empregada não tem querer. És muito bem paga!". O tom de voz da patroa subia a cada palavra, sua rispidez chegou ao ponto de ameaçar-me com a expulsão: "Se não tens profissionalismo para cumprir com tuas obrigações te vais embora daqui de uma vez, afinal, ainda que me doa fazer isso com alguém que foi criada como minha irmã, sei que será o melhor para nós duas! Te vais daqui com a roupa do corpo aprender a ser gente na rua!". Aquela possibilidade terrível de ver-se a mercê da cidade, solta na rua, a assaltou e estremeceu. Uma escuridão tomou conta da sua visão e quando deu por si estava sendo arrastada para fora da casa enquanto o corpo da patroa jazia no piso frio da cozinha, envolto em uma grossa poça de sangue quente. $\mathrm{O}$ piso que luzia limpeza era pouco a pouco tomado pela opacidade do líquido espesso a se espalhar. Seu primeiro pensamento foi “e agora, quem vai limpar essa sujeira toda?". Teve vontade de rir da situação: "Quem limpará isso? Ha ha ha!", pensou em um sorriso contido. Nem se debateu mais contra os dois homens da polícia que a arrastavam pelo braço. Calada na delegacia, assim permaneceu durante a larga viagem no camburão branco. Ficou a pensar em sua recém adquirida carteira de trabalho: ali ficaria registrada a mancha daquele fato por toda sua vida. Admirara tanto o cheiro sério das suas folhas oficiais, agora maldizia sua existência inflexível. De fato, quando da libertação dos escravos, a exigência do cadastro na Intendência Municipal ou Chefatura de Polícia dos novos trabalhadores domésticos livres foi considerada uma nova forma de escravidão (SILVA, 2013, p. 19). ${ }^{3}$

Toda forma de proteção é uma forma de controle. Os criados em especial vivem uma relação em muito regulada pela obediência em troca da proteção (GRAHAM, 1992). Mas resumir a postura serviçal de Tuta e suas colegas de profissão a isso é demais. Elas são também híbridos bizarros de parentes e profissionais liberais. Vivem entre a segurança e o risco, o medo e a inconsequência, o amor e o ódio. São íntimas e estranhas. Tuta se perdia em devaneios enquanto era levada em um novo camburão para seu destino final do cárcere:

A minha senhorinha meia irmã não podia ter me tratado assim. Resolvi tudo em casa mesmo. E agora eu preferia não ter documentos. Preferia estar amarrada só pelas cordas nas minhas mãos, não pela memória dos papéis e dos carimbos. Por mais que se lave essas marcas não saem. É como as chibatadas profundas no lombo das avós: fincava fundo na carne e brotava em vergão pra lembrar o dia da infração. Tenho marcada em meus documentos minha tentativa frustrada de justiçar meus afetos. O carro parou! Escuto meus acompanhantes de viagem dizerem que fiquei louca. Acho que eles têm razão, pois juro que eles acabam de me deixar diante de um grande palácio.

\footnotetext{
“'Art. $5^{\circ}$ - Nenhum contratador poderá despedir os contratados compreendidos no art. $1^{\circ}$ sem prévio aviso com antecipação de 10 dias, salvo justos motivos, uma enfermidade, embriagues, falta de respeito ou ócio e negligência; de que dentro de 24 horas dará conhecimento a Secretaria da Câmara municipal para fazer-se a devida observação no livro de registro" (Posturas Municipais, livro 1.8.1, ano 1829-1888, p. 34. Arquivo Histórico de Porto Alegre apud BELARDINELLI, 2009, p. 20).
}

\section{3) Saturação e implosão da civilidade disciplinar: das ruínas nasce o espetáculo}

Abro os olhos. Vejo o teto da minha casa. Ainda que meu teto não tenha sido feito com grande personalidade eu o reconheço claramente. Meu teto é liso. Ou melhor, reto. Pois possui algumas manchas de infiltrações e mofo que são a singular garantia de que despertei mais uma vez em minha casa. Mas, olhando bem... essa não é minha casa. $O$ prédio para o qual me trouxeram não era exatamente um palácio, ainda que parecesse um. Era uma casa de doidos. Minha quase-irmã-sempre-senhora sobrevivera ao ataque. Mas eu nem tanto. Para protegerme de mim e dos demais os homens da lei decidiram por não me trancafiar em uma carceragem comum. Ao invés disso eu deveria receber um tratamento especial. $\mathrm{O}$ teto era o de sempre: paredes úmidas e mal caiadas a mofarem vidas. Os poucos móveis também marcavam o parentesco entre os espaços. Assim como nos meus quartos anteriores, aquele quarto não era exatamente meu. Não era eu que decidia quem entrava nele, nem quando vinham as visitas. Mas aquele novo quarto guardava uma estranheza. Ele não servia só para que eu me escondesse e descansasse. Ele também servia para permitir que me vissem. A porta tinha duas aberturas que volta e meia rangiam por conta de alguma conferida. Janela eu tinha, mas cravejada de barras de ferro para que nada além da luz e do ar pudessem passar por ali. Acostumada a ser criada em terras que não me pertenciam, mas que eu pertencia a elas, logo me afeiçoei ao novo lar. Todo dia tinha algumas saídas: refeições, divertimentos e alguma conversa. Por vezes tomávamos a fresca nos pátios de onde víamos entre grades uma larga avenida que me gelava a espinha. Nestes momentos ficava feliz de estar protegida naquelas paredes. Minha nova casa tinha suas divisões: partes destinadas aos médicos, aos enfermeiros, aos secretários, ao pessoal da limpeza e aos moradores. Ficava a olhar aquela gente de azul a varrer, esfregar e desinfetar. Era estranho ter alguém limpando as coisas para mim. Mas já havia entendido as divisões daquele palácio e nelas não cabia a mim o serviço. Eu tinha de acompanhar as pessoas de branco e não as de azul, pois minha função era ir nas reuniões dos médicos e enfermeiros para deixá-los felizes. Eu sempre ia. Chegava na hora certa sem reclamar e realizava todas as atividades com um sorriso no rosto. Tal como sempre fizera em toda minha vida. Pintava, bordava, dançava, fazia o que me pediam. Pra minha surpresa um dia me deram vassoura, pano, balde e me pediram para ajudar na limpeza. Não posso negar que fiquei feliz, pois aquela falação toda era muito entediante. Precisava me mexer. E não dançando ou pintando, pois nunca fui de dançar e pintar. Ao menos nunca dancei muito. Tanto ajudei que um dia me ajudaram: me chamaram em uma daquelas salas dos secretários e me disseram que eu iria voltar pra Pelotas. Até uma casa tinham arrumado. Não foi fácil abandonar meu novo quarto. Eles insistiram bastante, disseram que ia ser melhor para mim e que todos os moradores sairiam de lá. Como nada ali a 
mim pertencia, tive de aceitar me ir. Mais de vinte anos tinham se passado desde minha entrada naquele palácio, eu estava com receio de abandonar minha nova velha morada. Por isso aceitei e saí: me fui de volta para outro quarto meu que meu não era.

\section{1) A internação de Tuta no doméstico: o residencial terapêutico}

Tuta foi deslocada para um residencial terapêutico onde já moravam outros dois usuários do SUS que perderam seus vínculos familiares, sociais e econômicos com o mundo dos sãos. Moravam em uma casa simples no centro da cidade de Pelotas. Os ruídos constantes vindos da rua incomodavam Tuta, mas as paredes e fechaduras da casa lhe permitiam respirar aliviada. Havia um quintal nos fundos da casa onde havia um tanque e um muro. Tuta estava juntando garrafas de vidro vazias para quebrá-las e fixar os pedaços com cimento no alto do muro. Vira certa feita a obra de Arthur Bispo do Rosário denominada "434 - como - é que eu - devo fazer um muro no fundo da - minha casa -": um pedaço retangular de madeira com cacos de vidro fixados por uma massa amarronzada. Aquela imagem não saíra de sua cabeça. Ela também precisava garantir que a loucura da rua não inundasse o sacrossanto espaço doméstico. Os moradores do residencial não conversavam muito, raramente trocavam algum resmungo sobre uma notícia ou cena de novela. Suas brigas se resumiam ao litígio sobre qual canal assistir. Não tinham muito em comum, vieram de diferentes cidades sem jamais terem se visto antes. Sua convivência fora imposta pela regulamentação que normatiza o público alvo do residencial terapêutico: pessoas com certidão de nascimento de Pelotas que tenham sido internadas por ao menos dois anos ininterruptos em qualquer instituição manicomial. Tuta ficava isolada a escutar o rádio na cozinha, sentia-se mais segura. Não gostava nem de ficar a ver o movimento na janela. Se ela pudesse mandaria concretar aquele buraco. $\mathrm{Na}$ escuridão das cortinas sempre fechadas, Tuta percebeu um pequeno musgo a crescer no seu corpo. Pouco a pouco ele foi se espalhando pelos membros, enlaçando juntas, entrando nas narinas e ouvidos. À medida que crescia o vegetal, uma sensação de tédio tomava conta do passar das horas. $\mathrm{O}$ tédio, que iniciara médio, se intensificou e beirou o desespero. $\mathrm{O}$ ar era abafado e irrespirável. As paredes pareciam se fechar sobre seu corpo como um caixão fúnebre de alvenaria. Foi quando as paredes que eram delimitadoras do seu dormitório se transformaram nas paredes da ala de criadas no antigo casarão de charqueada, nas paredes da dependência de empregada do apartamento da patroa assassinada, nas paredes da pequena cela do velho hospício, até voltarem a ser as paredes do dormitório no residencial terapêutico. Agora estava louca ou percebera o óbvio?

Tuta se levantou com dificuldade, caminhou vagarosa até o banheiro, lavou cuidadosamente seu corpo retirando a vida que se nutria do seu tédio doméstico. Vestiu sua melhor roupa. Parou estacada diante da porta para a rua. Destrancou os vários miolos das fechaduras e escancarou a porta recebendo uma lufada de vento e ruído. Saiu da casa sem fechar a porta atrás de si. Caminhou sem objetivo pelas calçadas da cidade. Tuta se equilibrava com a docilidade de uma bailarina senil, vencendo doce os encontrões áridos dos corpos jovens e afoitos que pediam passagem pela pressa. Já ela, andava com a calma dos sem futuro. Mirava admirada a fachada carcomida dos antigos casarões. Pareciam carcaças mortas, mas Tuta percebeu vida pulsando sob a arquitetura degradada. Tal como nos cadáveres que descansam sob o solo, uma multidão de novas vidas ali pululava. Existia um intenso fluxo de entra e sai das casas. Algumas tinham sido invadidas, outras apenas herdadas como capital ralo. Mas estas vidas esguias eram pouco notáveis. As pessoas diziam que aquelas zonas do centro estavam mortas e necessitavam de revitalização. Como podiam estar mortas com tanta gente morando ali? Era possível avistar as cenas das batalhas pela retomada do espaço: casarões bem pintados, fachadas com andaimes sendo restauradas, cafés e confeitarias se multiplicando no entorno de elegantes espaços culturais. Pelotas retomava seu rigor cultural pouco a pouco. Se antes fora necessário comprar títulos de nobreza com dinheiro vindo da carne das rezes e escravos, hoje a retomada se dava mirando ao turismo e consumo através de incentivos fiscais federais.

Já era noite e Tuta precisava encontrar um espaço para inventar um mocó e dormir. Lembrou-se da antiga fonte na Praça Pedro Osório. Sabia que o antigo passeio dos civilizados fazia tempo havia se degradado. Como um baluarte da implosão sob a própria gravidade da civilidade disciplinar, a praça bem diante da prefeitura era um espaço para além da sua capacidade de governo. Lá proliferava todo tipo de erva nas brechas da civilidade urbana. A antiga fonte envolta em grafite e lixo, era apenas uma lembrança de um projeto falido. Imaginem qual não foi a surpresa de Tuta ao se deparar com a praça tomada por luzes multicoloridas, música e uma fonte de águas dançantes ao estilo Vegas. Todas aquelas lâmpadas e gente luzindo na praça faziam dela uma pequena passagem comercial a céu aberto: a opulência civilizatória voltara ao centro. Uma multidão de bons homens estava prostrada em torno da fonte a mirar o espetáculo.

Se relembramos o trajeto da antiga fonte francesa da praça Pedro Osório, vemos que sofreu alguns deslocamentos: pelourinho, fonte de coleta d'água, adorno civilizado, patrimônio degradado, espetáculo revitalizado. Do lodo escravocrata brotara aquela flor, que fora cercada pelo ímpeto disciplinar higienista. Mas ímpeto e cerca se degradaram. A antiga fonte passou a servir de alcoviteira dos infames nas longas noites do sul. No entanto, em plena virada para o novo século, outra estratégia buscou tomar de assalto o antigo ícone da civilidade Pelotense: o espetáculo revitalizador. O centro da praça passou do espetáculo cruel do pelourinho para o show mansinho das águas dançantes. Havia que substituir os andarilhos maltrapilhos por turistas em pleno exercício da sua cidadania consumidora. Eles eram atraídos pela luz como mariposas progressistas, enquanto os mortosvivos fugiram cegados pela claridade do espetáculo e suas autoridades policiais. Tuta nem precisara ser 
abordada pelos agentes da ordem. Bem educada que era, logo percebeu que aquelas luzes faziam as vezes de paredes: ali não era lugar para ela. Nas brumas de um beco próximo encontrou abrigo coberta pelas letras que anunciavam esfuziantes a inauguração da bendita fonte.

O dia amanhecera. Acordou com a movimentação de outros corpos imundos de mundo por dormitarem no chão da cidade. Retirou as letras que cobriam suas pernas e perguntou àquele povo ocre para onde iam. Lhe disseram que iam em busca do almoço e banho em um tal de CREAS POP. Ao que parece lá havia todo um grupo de benfeitores fidalgos que ajudavam aos mais necessitados. Ela os seguiu curiosa por conhecer aquela casa dos sem casa. Ao chegar no CREAS, logo foi reconhecida pela assistente social da prefeitura que lhe recebera no residencial terapêutico. Assustada, a assistente lhe inquiriu o que fazia na rua e lhe advertiu que aquilo não estava bem: "deves ficar em casa! na rua é muito perigoso para ti! mas pode deixar, fica aí esperando que te levarei de volta já-já”. Tuta não queria ir, mas aprendera desde moça a não contrariar e ficou ali aguardando até que a assistente lhe buscou. No caminho, ela explicava que Tuta não devia sair por aí sem destino, podia dar passeios e ir às oficinas do CAPS, mas não podia expor sua vida ao risco como tinha feito. Não podia abrir a porta da casa para estranhos e tinha de mantêla sempre bem trancada. Podia sair de casa, mas tinha que voltar cedo, ter horários, construir rotina. Tuta não sabia, mas para ser livre tinha de ficar dentro de casa e do hábito. Depois de tanto esforço para colocar o pé na rua, trancou-se logo após a saída da profissional. Guardou minuciosamente a chave em seu bolso com um alfinete de segurança. Fitou seus companheiros iluminados pela luz azul. Respirou fundo, afundou como pedra no sofá e enfim resolveu ver tevê.

\section{No sofá: as novas segmentações de um mundo flexível e disperso}

As novas segmentariedades urbanas ${ }^{4}$ solaparam Tuta da sua deriva: da exclusão à exclusividade (COSTA, 2007). A reversão da lógica disciplinar virou as grades do avesso, agora elas servem para manter a homogeneidade do lado de dentro das grades e não mais do lado de fora. A norma se pulveriza em uma série de modulações espaciais com senhas específicas para cada gueto urbano. Da favela ao condomínio fechado, a lógica do autoencarceramento venceu por fim. A cidade controlada dos urbanismos planificados findou por voltar-se para a arquitetura de interiores em condomínios, prédios e casas. Deste modo, hoje, baseados em tal micropolítica do medo, diversos equipamentos de segurança são criados e implementados para melhor elevar as fronteiras do privativo. Da mesma forma, cada vez mais se amplia a autonomia dos lares com tecnologias virtuais da comunicação, eletrodomésticos

\footnotetext{
4"Em lugar do grande medo paranoico, encontramo-nos presos por mil monomaniazinhas, evidências e clarezas que jorram de cada buraco negro e que não fazem mais sistema e sim rumor e zumbido, luzes ofuscantes que dão a qualquer um a missão de um juiz, de um justiceiro, de um policial por conta própria, de um gauleiter, um chefete de prédio ou de casa. Vencemos o medo, abandonamos as margens da segurança, mas entramos num sistema não menos concentrado, não menos organizado, um sistema de pequenas inseguranças" (DELEUZE; GUATTARI, 1996, p. 102).
}

e toda uma variedade de equipamentos para diversas atividades que passam a se realizar em casa. Assim, vemos que somado à dispersão, atua uma totalização do espaço privativo, com a contração do seu espaço em uma autonomização do lar perante a malha urbana. Todas estratégias de segurança se apoiam na tensão entre segurança e liberdade (vista aqui como possibilidades de possibilidades, o que incorre em risco e incerteza), tal como as tensões que permearam a vida de Tuta: tutela e cuidado, proteção e opressão. Ensimesmados, apelamos para o consumo da democracia em uma democracia do consumo, enquanto nos utilizamos dos direitos humanos como estratégia para garantir nossa liberdade de permanecer trancados entre iguais. Protegidos pelas exclusividades da cidade privatizada: casa, carro, clube, shopping. Junto de Tuta, devemos nos perguntar quais riscos estamos dispostos a viver para experimentar outras cidades e domesticidades possíveis. $\mathrm{O}$ que diremos aos infantes sobre os estranhos, como lidaremos com nossas trancas, como nos deslocaremos pelas ruas e em que ruas? Com quem nos encontramos e como? Sentados em nossas casas escrevendo ou lendo este pequeno ensaio, podemos nos questionar se estamos dispostos a abrir nosso cotidiano a misturas menos dóceis que o doce lar da domesticidade contemporânea.

\section{Referências}

BELARDINELLI, L. Do serviço doméstico: o cotidiano das criadas negras em Porto Alegre, 1880-1888. 2009. TCC (Graduação)-Departamento de História, Universidade Federal do rio Grande do Sul, Porto Alegre, 2009.

CARVALHO, V. C. de. Gênero e artefato: o sistema doméstico na perspectiva da cultura material - São Paulo, 1870-1910. São Paulo: Universidade de São Paulo/ Fapesp, 2008.

COMTE, A. Catecismo Positivista. In: GIANNOTTI, A. (Org.). Comte. São Paulo: Abril Cultural, 1978. Coleção Os Pensadores.

COSTA, L. A. Brutas cidades sutis: o espaço tempo da diferença na contemporaneidade. 2007. Dissertação (Mestrado)-Programa de Pós-graduação em Psicologia Social e Institucional, Universidade Federal do Rio Grande do Sul, Porto Alegre, 2007. Disponível em: <http://hdl.handle. net/10183/13404>. Acesso em: 20 out. 2014.

CUNHA, O. M. G. da. Criadas para servir: domesticidade, intimidade e retribuição. In: CUNHA, O. M. da; GOMES, F. S. (Org.). Quase-cidadão: histórias e antropologias da pósemancipação no Brasil. Rio de Janeiro: FGV, 2007. p. 378-418.

DELEUZE, G.; GUATTARI, F. Mil platôs: capitalismo e esquizofrenia. Rio de Janeiro: Ed. 34, 1996. v. 3.

DELEUZE, G.; GUATTARI, F. O que é a filosofia? São Paulo: Ed. 34, 1997.

GRAHAM, S. L. Proteção e obediência: criadas e seus patrões no Rio de Janeiro, 1860-1910. São Paulo: Companhia das Letras, 1992. 
GILL, L. A. Labirintos ao redor da cidade: as vilas operárias em Pelotas (RS) 1890-1930. História Unisinos, v. 10, n. 1, p. 45-52, jan./abr. 2006.

LORNER, B. A.; GIL, L. A.; SCHEER, M. I. Enfermidade e morte: os escravos na cidade de Pelotas, 1870-1880. História, Ciências e Saúde-Manguinhos, Rio de Janeiro, v. 19, supl. 1, p. 133-152, dez. 2012.

MARTINS, R. A. et al. Contágio: história das doenças transmissíveis. São Paulo: Moderna, 1997.

MÜLLER, D. "Feliz a população que tantas diversões $e$ comodidades goza": espaços de socabilidade em Pelotas (18401870). 2010. Tese (Doutorado)-Programa de Pós-Graduação em História, Universidade do Vale do Rio dos Sinos, São Leopoldo, 2010.

SENNETT, R. Carne e Pedra: o corpo e a cidade na civilização ocidental. Rio de Janeiro: Record, 1997.

SEVCENKO, N. (Org.). A capital irradiante: técnica, ritmos e ritos do Rio. In: . História da vida privada no Brasil. São Paulo: Companhia das Letras, 1998. p. 513-619.

SILVA, M. H. O trabalho doméstico livre e a lei nos anos finais da escravidão no Brasil. In: ENCONTRO ESCRAVIDÃO E LIBERDADE NO BRASIL MERIDIONAL, 6., 2013, Florianópolis. Anais... Florianópolis: UFSC, 2013. Disponível em: <http://labhstc.paginas.ufsc.br/files/2013/04/MacielHenrique-Carneiro-da-Silva-texto.pdf $>$. Acesso em: 21 fev. 2014.

SOARES, P. R. R. La difusion del higienismo en Brasil y el saneamiento de Pelotas (1888-1930). Scripta Nova - Revista Electrónica de Geografía y Ciencias Sociales, Barcelona, v. 69, n. 38, ago. 2000. Disponível em: <http://www.ub.edu/geocrit/ sn-69-38.htm>. Acesso em: 19 fev. 2014.

SYMANSKI, L. C. P. Espaco privado e vida material em Porto Alegre no século XIX. Porto Alegre: Edipucrs, 1998.

XAVIER, J. S. Saneamento de Pelotas (1871-1925): o patrimônio sob o signo da modernidade e progresso. 2010. Dissertação (Mestrado em Memória Social e Patrimônio cultural)-Universidade Federal de Pelotas, Pelotas, 2010.

Recebido em: 16 de março de 2015 Aceito em: 26 de março de 2016 